DOI: https://doi.org/10.24144/2409-6857.2018.1(51).430-435

УДК 657.37

\author{
Олійник Є.В.
}

\title{
АУДИТ В УКРАЇНІ: СТАНОВЛЕННЯ, ПРОБЛЕМИ ТА ПЕРСПЕКТИВИ РОЗВИТКУ
}

\begin{abstract}
У статті викладені результати дослідження особливостей становлення аудиту в Україні. Автором представлено чотири періоди розвитку національного аудиту: «зародження аудиту» (1987-1989 рр.); «становлення украӥнського аудиту» (1989-1992 рр.); «юридичне становлення» (1993-2001 рр.); «сучасний аудит» (2007-по теперішній час). В статті розглянуто і систематизовано найбільш вагомі проблеми розвитку вітчизняного аудиту з урахуванням євроінтеграційного розвитку економіки. В результаті проведеного аналізу досліджень автором узагальнено шляхи вирішення проблем та вказано перспективи розвитку аудиту в Украӥні.
\end{abstract}

Ключові слова: аудит, аудиторська діяльність, фінансовий контроль, європейська інтеграція

Постановка проблеми. На сьогодні взаємозв'язок між суб'єктами господарювання певною мірою характеризує сучасний стан економіки. Професійний захист інтересів власників капіталу набуває важливого значення через зростання ризикових операцій та прийняття економічних рішень в умовах невизначеності. Забезпечення фахового супроводження фінансово-господарської діяльності в світовій практиці здійснюють аудиторські фірми. За період незалежності в Україні створено національну систему аудиту, структура, забезпечення та функціонування якої постійно удосконалюється. Проте організація вітчизняного аудиту не повністю відповідає загальноєвропейським нормам. Інтеграція України у СС залежить від потреб у гармонізації аудиторських механізмів і національного обліку у європейських масштабах. Хоча на сьогодні відбувається активний розвиток вітчизняного незалежного аудиту, $\epsilon$ певні проблеми, які потребують вагомої уваги науковців і практиків.

Аналіз останніх досліджень і публікацій. Тенденції розвитку аудиту в Україні відображено у працях таких учених-економістів: Ф.Ф. Бутинець [5], Я.А. Гончарук [14], С.I. Дерев' янко [6], А.О. Касич [8], Н.П. Кузик [6], С.О. Олійник [6], В.С. Рудницький [14], М.М. Хоменко [15] та ін. Загалом вчені виділяють три періоди розвитку аудиту в Україні: (1987-1992 рр.) створення перших аудиторських структур, (1993-1998 рр.) формування нормативно-правової бази аудиту в Україні, (1999р - до тепер) діяльність аудиту в новій нормативно-правовій базі. Вагомий внесок

(C) Олійник Євгенія Валеріївна, к.е.н., старший викладач кафедри обліку i фінансів факультету економіки, Кременчуцький національний університет імені Михайла Остроградського, м. Кременчук, тел.: +380965120158, email: oliinyk.evgenia@gmail.com щодо аналізу ринку аудиторських послуг та тенденцій його розвитку зроблено у публікаціях Касич А.О.[8]. Взявши до уваги бачення кожного автора, бажаємо висловити власну думку щодо становлення аудиту в Україні.

Дослідження проблем та перспектив розвитку національної аудиторської діяльності можна знайти в працях таких науковців, як: В. Бандура [3], Ю.Ю. Борисова [4], М. Йосипович [7], Д. Кузів [3], С.В. Медвідь [10], В. Мелех [3], I.А. Платонова [13] та ін. Відмітимо, що у науковому дискурсі малодослідженими i невирішеними є проблеми аудиторської діяльності в контексті сучасної євроінтеграційної політики України. Враховуючи те, що на сьогодні місце України серед європейських країн та їі імідж у світі залежить від принципово нових викликів щодо розвитку вітчизняного аудиту, то визначення першочергових проблем аудиторської діяльності, які гальмують розвиток членства України до $Є С$, та їх вирішення має актуальне значення.

Формулювання цілей наукової статті. Метою статті є дослідження становлення аудиту в Україні, визначення проблем та перспектив розвитку в сучасних умовах євроінтеграції.

Опис основного матеріалу дослідження. Розвиток ринкових відносин та виникнення недержавної форми власності сприяли розвитку такої форми контролю як аудит. Загалом під аудитом розуміють певний процес, за допомогою якого проводиться оцінка свідчення про інформацію 3 метою визначення і висловлення думки щодо ступеня іiі відповідності певним критеріям компетентним незалежним фахівцем. Аудит як незалежний фінансовий контроль у світі за історичними джерелами має багатовіковий період розвитку та був запозичений у вітчизняну практику для перевірки достовірності та законності фінансової звітності діяльності підприємств. У Великобританії регулювання 
обов'язкового проведення аудиту започатковано у 1844 р., в результаті чого керівники акціонерних компаній були зобов'язані щорічно запрошувати незалежного аудитора для перевірки та підтвердження фінансових звітів, які надавались акціонерам. Згодом аналогічні закони прийняті у Франції в 1867 р. та США в 1887 р. Отже як самостійна професія аудит сформувалась у другій половині IX ст. Відтоді і до тепер громадський інститут аудиту 3 правовою та організаційною структурою існує в усіх країнах світу з ринковою економікою.

У нашій країні аудит на початку свого становлення мав лише практичне спрямування, адже аудиторам-практикам не вистачало теоретичних i наукових знань 3 методології $\mathrm{i}$ організації аудиту. Умовно автором виділено чотири періоди становлення вітчизняного аудиту (таблиця 1).

\section{Періоди становлення аудиту в Україні*}

\begin{tabular}{|c|c|c|c|c|}
\hline \multicolumn{2}{|c|}{ Період } & \multirow{2}{*}{$\begin{array}{c}\text { Назва } \\
\begin{array}{c}\text { Зародження } \\
\text { аудиту }\end{array}\end{array}$} & Характеристика & $\begin{array}{c}\text { Передумови становлення та } \\
\text { розвитку }\end{array}$ \\
\hline Перший & $\begin{array}{c}\text { 1987-1989 } \\
\text { pp. }\end{array}$ & & 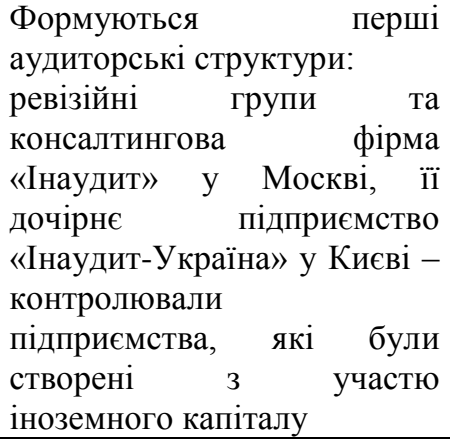 & $\begin{array}{l}\text { Потреба користувачів } \\
\text { достовірній та повній інформації } \\
\text { про фінансово-господарську } \\
\text { діяльність суб’єкта }\end{array}$ \\
\hline Другий & $\begin{array}{c}\text { 1989-1992 } \\
\text { pp. }\end{array}$ & $\begin{array}{l}\text { Становлення } \\
\text { українського } \\
\text { аудиту }\end{array}$ & $\begin{array}{ll}\text { Збільшуються } & \text { кількості i } \\
\text { форми } & \text { аудиторських } \\
\text { структур } & \\
\end{array}$ & $\begin{array}{l}\text { Необхідність } \\
\text { підтвердження } \\
\text { діяльності фірм }\end{array}$ \\
\hline Третій & $\begin{array}{l}\text { 1993-2001 } \\
\text { pp. }\end{array}$ & $\begin{array}{l}\text { Юридичне } \\
\text { формування } \\
\text { аудиту }\end{array}$ & $\begin{array}{l}\text { Створюється нормативно- } \\
\text { правова база аудиту }\end{array}$ & $\begin{array}{lc}\text { Необхідність } & \text { розвитку та } \\
\text { уніфікації } & \text { аудиторської } \\
\text { діяльності } & \\
\end{array}$ \\
\hline Четвертий & $\begin{array}{l}\text { 2007-по } \\
\text { теперішній } \\
\text { час }\end{array}$ & $\begin{array}{c}\text { Сучасний } \\
\text { аудит }\end{array}$ & $\begin{array}{l}\text { Відбувається реформування } \\
\text { аудиту в Україні відповідно } \\
\text { до міжнародно-визнаних } \\
\text { вимог, вносяться зміни до } \\
\text { вітчизняного законодавства }\end{array}$ & \begin{tabular}{lcr} 
Важливість & \multicolumn{2}{c}{ гармонізації } \\
аудиторських & механізмів \\
національного & обліку \\
європейських масштабах & у
\end{tabular} \\
\hline
\end{tabular}

* Складено автором

У першому періоді «Зародження аудиту» створювались в Україні перші аудиторські структури. Так, із виникненням ринкових відносин і створенням в УРСР спільних підприємств на вимогу іноземного інвестора постала потреба у достовірній оцінці майна в умовах інфляції та приведення його вартості у відповідність з ринковою аудитором. Саме тому створилась перша аудиторська фірма в Україні «Інаудит-Україна», до складу якої входили колишні держслужбовці контрольно-ревізійного управління Міністерства Фінансів України. Найперші аудиторські фірми проводили консультації щодо складання звітності, ведення загалом бухгалтерського обліку, оподаткування та безпосередньо контролювали підприємства, які були створені з участю іноземного капіталу. На той час значна кількість бухгалтерів малих підприємств мала низьку кваліфікацію, а законодавство постійно зазнавало змін, отже необхідність в аудиті була об’ єктивною.
У другому періоді «Становлення украӥнського aудиту» було створено Спілку аудиторів України (професійне громадське об'єднання громадян, яке вже на першому з'їзді прийняло статут спілки аудиторів України). Можна зазначити, що становлення вітчизняного аудиту при переході до ринку сприяло розпаду минулої системи організації обліку і контролю. Дерев'янко С.І., Кузик Н.П., Олійник С.О. [6] зазначають, що на той час кількість суб'єктів аудиторської діяльності була невелика на ринку аудиторської діяльності, тож основною рисою даного періоду можна вважати відсутність конкуренції.

Третій період «Юридичне становлення» характеризується інтенсивною розробкою та впровадженням нормативно-правових актів щодо регулювання аудиторської діяльності. Створено Аудиторську палату України як самостійний та незалежний орган. 22 квітня 1993 р. прийнято 3У «Про аудиторську діяльність в Україні» №3125- 
XII [1], завдяки чому відбулось офіційне визнання обов'язкового аудиту. Багато науковців вважають, що реальне формування аудиторської практики було започатковане саме прийняттям даного закону. Такої думки Бутинець Ф.Ф. [5], Рудницький В.С., Гончарук Я.А. [14] та ін. Звичайно, спочатку примусове запровадження аудиту в Україні викликало негативне ставлення у підприємців, проте потім 3 кожним роком престижність професії аудитора в суспільстві збільшувалась та зараз широко використовуються послуги аудитора серед користувачів.

У четвертому періоді «Сучасний аудит» аудитори легально здійснюють оцінку, ведуть бухгалтерський облік, консультують замовників, проводять професійні тренінги. Відмітимо, що на сучасному етапі розвитку економіки ринок аудиторських послуг переорієнтовується. Так, раніше в аудиті була потреба у замовників, які мали обов'язково проводити щорічну перевірку, але зараз користуються попитом і інші послуги. Коли керівництву компанії цікаво не лише знати, чи об'єктивна та достовірна інформація звітності, а важливо перевірити діяльність іiі філій, ефективність окремих напрямів діяльності чи як здійснюється виконання контрактів, то тоді i виникає потреба у специфічних послугах аудиторів. Хоменко М.М. наголошує, що аудиторські фірми повинні «...направляти зусилля на надання широкого спектру послуг, починаючи 3 ведення обліку та закінчуючи консалтингом, бухгалтерським аутсорсингом, Дью Дилидженсом, автоматизацією, бюджетуванням, питаннями бізнес-проектів, розробкою та впровадженням програмного забезпечення, автоматизацією податкових розрахунків та екологічних показників та ін. Це пояснюється намаганням утримати клієнтів, знаходячи альтернативні джерела доходів.» [15].

Проте на сьогодні організація аудиту в Україні не відповідає загальноєвропейським нормам. Розвиток України на шляху до членства в ЄC вимагає реформування аудиту до міжнародно-визнаних вимог. Головною вимогою посилення вимог до вітчизняного аудиту $\epsilon$ підвищення довіри до даних фінансової звітності для іноземних інвесторів та інших користувачів інформації. Певні кроки адаптації національного законодавства у сфері аудиту до вимог СС були зроблені, а саме: запроваджено сертифікацію аудиторів та впроваджено вимогу із зовнішньої перевірки якості аудиторських послуг; дозволено здійснювати діяльність у сфері аудиту лише тим суб'єктам аудиторської діяльності, що пройшли перевірку якості з боку АПУ. Не менш важливим $\epsilon$ i впровадження Міжнародних стандартів аудиту [11] та схвалення плану імплементації Директиви 2006/43/€C [2] та ін. Євроінтеграційний розвиток економіки у перспективі відкриває можливості виходу на нові ринки, що для українських споживачів послуг аудиторів надасть можливість отримати якісні послуги, сплативши за них справедливу ціну.

Проте варто зазначити, що існують вагомі проблеми, які стримують розвиток національного аудиту, в результаті чого лишається низька ефективність аудиторської діяльності вітчизняних підприємств. Йосипович М. зазначає, що «...нормативноправові акти, які визначають проведення аудиту у різних сферах економічної діяльності, неоднозначно трактують як сутність аудиту, так $\mathrm{i}$ вимоги до суб'єктів його проведення. Міжнародні стандарти аудиту та напрацювання Аудиторської палати України щодо національної практики аудиту поширюються виключно на сферу фінансового контролю. На практиці ж сфери застосування аудиту значно ширші. На сьогодні склався достатньо широкий термінологічний словник з аудиту, закріплений у навчальній літературі, законах та нормативних документах міністерств і відомств України, який у підсумку зводиться до таких понять: «податковий аудит», «екологічний аудит», «технічний аудит», «аудит систем управління якістю», «аудит газотранспортної системи», «енергетичний аудит», «земельний аудит»» [7].

Медвідь С.В. наголошує, що «...розвиток ринку аудиторських послуг в Україні стримується за рахунок таких факторів: відсутність критичної маси середнього класу, який $\epsilon$ активним гравцем на ринку цінних паперів, разом 3 нерозвиненістю фондового ринку; високий ступінь корумпованості економічних відносин; копіювання нормативного та методологічного забезпечення аудиторської діяльності 3 моделей високо розвинутих країн без належного адаптування до національних реалій; відсутність національної системи зовнішнього контролю якості аудиту, а також методики оцінки розмірів збитку від неякісно наданих аудиторських послуг; нерозвиненість механізмів страхування відповідальності аудиторських фірм перед клієнтами за неналежне надання послуг 3 аудиту» [10].

Платонова I.A. вказує на такі проблеми розвитку аудиту в Україні, як «...недостатня кількість кваліфікованих аудиторських кадрів, а звідси - i неосвоєний ринок аудиторських послуг; брак достатнього досвіду аудиторської діяльності; відсутність типових форм документів 3 аудиту; відсутність методичних 
рекомендацій з питань комп'ютеризації аудиту тощо; відсутність розробленого економічного механізму щодо регулювання аудиту, який включає в себе великі штрафні санкції за неякісні аудиторські перевірки, страхування аудиторської відповідальності (страхові фірми не здатні і не підготовлені до масового страхування аудиторської відповідальності), розвиток цивілізованої конкуренції на ринку аудиторських послуг тощо; недосконалі законодавча база i досвід судового розгляду позовів щодо аудиторів (аудиторських фірм), немає методики оцінки розмірів збитку користувачів від не якісного аудиту; недостатня кількість методичних розробок з аудиторського контролю» [13].

Борисова Ю.Ю. наголошує, що «на українському ринку праці існує недостатня кількість досвідченого персоналу в галузі управління і особливо в тих галузях, які були погано розвинені в нашій країні. Менеджери із західних компаній приносять 3 собою знання технологій операційної діяльності, бачення тенденцій розвитку ринку, IT-технологій» [4]. Також автор стверджує, що «..невирішеною і серйозною проблемою для розвитку галузі залишається демпінг цін. Зокрема, на ринку продовжує функціонувати досить велика кількість компаній, які надають послуги 3 необгрунтовано заниженими цінами, тобто послугами низької якості. При цьому потрібно зазначити, що неякісні аудиторські послуги не тільки ставлять авторитет професії під великий сумнів, а й перешкоджають розвиткові галузі в цілому» [4].

\begin{tabular}{|c|c|}
\hline \multicolumn{2}{|c|}{ Розвиток аудиту в Україні } \\
\hline \multicolumn{2}{|c|}{$\begin{array}{l}\text { Періоди становлення: } \\
\text { - перший період (1987-1989 рр.) «Зародження аудиту»; } \\
\text { - другий період (1989-1992 рр.) «Становлення українського аудиту»; } \\
\text { - третій період (1993-2001 рр.) «Юридичне формування аудиту»; } \\
\text { - четвертий період (2007-по теперішній час) «Сучасний аудит». }\end{array}$} \\
\hline $\begin{array}{l}\text { Проблеми національного аудиту: } \\
\text { 1. Недосконалість законодавчої бази; } \\
\text { 2. Відсутність повної довіри щодо якості і } \\
\text { достовірності аудиторських послуг з боку } \\
\text { іноземних користувачів; } \\
\text { 3. Відсутність фіксованих цін на аудиторські } \\
\text { послуги; } \\
\text { 4. Недостатня кількість кваліфікованих } \\
\text { аудиторів; } \\
\text { 5. Недотримання аудиторами якості послуг; } \\
\text { 6. Відсутність покарань за недостовірну } \\
\text { інформацію у звітах аудитора; } \\
\text { 7. Відсутність вітчизняних аудиторських } \\
\text { фірм у міжнародних } \\
\text { об'єднаннях. аудиторських }\end{array}$ & 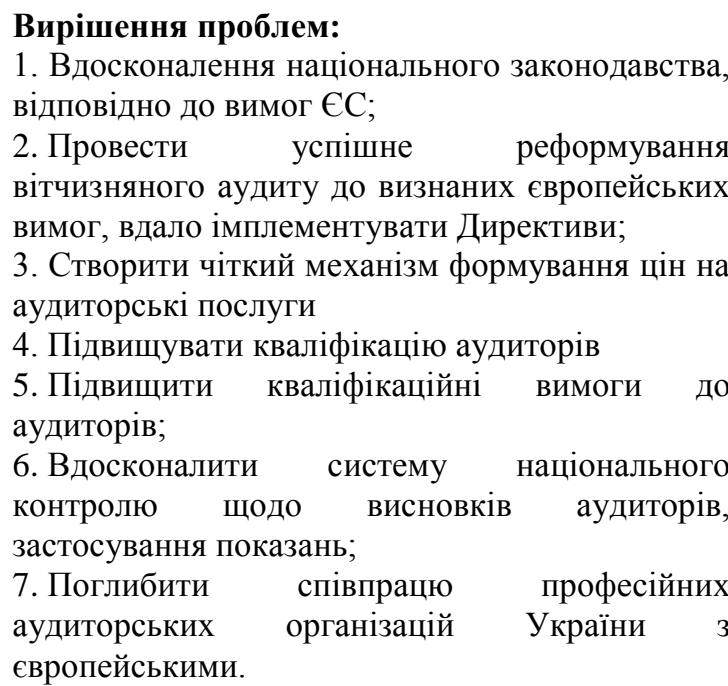 \\
\hline \multicolumn{2}{|c|}{$\begin{array}{l}\text { Перспективи розвитку вітчизняного аудиту: } \\
\text { 1. Покращення якості аудиту та підвищення довіри громадськості до професії аудитора шляхом } \\
\text { успішного впровадження Директив СС; } \\
\text { 2. Вихід вітчизняних аудиторських фірм на європейські ринки; } \\
\text { 3. Підвищення міжнародного авторитету України через імплементацію Директив; } \\
\text { 4. Підвищення прогресу економіко-правових відносин та демократизації суспільної сфери. }\end{array}$} \\
\hline
\end{tabular}

Рис. 1. Становлення, проблеми та перспективи розвитку аудиту в Україні *Побудовано автором

Бандура В., Кузів Д., Мелех В. виділяють такі проблеми вітчизняного аудиту, як «...недосконалість теоретико-прикладних та методичних матеріалів 3 аудиторського контролю; низька довіра до аудитора; значний негативний вплив «тіньового» бізнесу; недостатній практичний досвід аудиторської діяльності; низький рівень кваліфікованих аудиторських кадрів; недотримання аудиторами якості аудиторських послуг; відсутність штрафів та покарань за недостовірність звіту аудитора; відсутність чіткого механізму формування ціни 
на аудиторські послуги; відсутність методичних рекомендацій 3 питань комп'ютеризації аудиту негативний вплив дослівного перекладу закордонних стандартів i концепцій без врахування особливостей економічного розвитку нашої країни; відсутність типових формулярів документів 3 аудиту» [3].

Висновки i перспективи подальших досліджень. Загалом, на основі проведеного дослідження автором виділено періоди становлення вітчизняного аудиту, основні вагомі проблеми та перспективи його розвитку (рис.1).

3 урахуванням євроінтеграційного розвитку економіки автором доцільно виділити такі основні першочергові проблеми, які стримують розвиток вітчизняного аудиту, як: недосконалість законодавчої бази; відсутність повної довіри щодо якості i достовірності аудиторських послуг 3 боку іноземних користувачів; відсутність фіксованих цін на аудиторські послуги; недостатня кількість кваліфікованих аудиторів; недотримання аудиторами якості послуг; відсутність покарань за недостовірну інформацію у звітах аудитора; відсутність вітчизняних аудиторських фірм у міжнародних аудиторських об’єднаннях.

Для вирішення проблем необхідно: вдосконалити національне законодавство відповідно до вимог ЄС; провести успішне реформування вітчизняного аудиту до визнаних європейських вимог, вдало імплементувати Директиви; створити чіткий механізм формування цін на аудиторські послуги; підвищувати кваліфікацію аудиторів; підвищувати кваліфікаційні вимоги до аудиторів; вдосконалити систему національного контролю щодо висновків аудиторів, застосування показань; поглибити співпрацю професійних аудиторських організацій України 3 європейськими. Хоча і існують певні проблеми, подальше вдосконалення національного аудиту має значні перспективи його розвитку, а саме: покращення якості аудиту та підвищення довіри громадськості до професії аудитора шляхом успішного впровадження Директив $\mathrm{EC}$; вихід вітчизняних аудиторських фірм на європейські ринки; підвищення міжнародного авторитету України через імплементацію Директив; підвищення прогресу економіко-правових відносин та демократизації суспільної сфери. Подальший розвиток сприятиме позитивним змінам на організаціях, фірмах і тому важливим $є$ рахування досвіду інших країн для успішного удосконалення ведення аудиту в Україні.

Перспективою подальших досліджень $\epsilon$ вивчення удосконалення аудиторських механізмів в умовах євроінтеграційної політики України на основі зарубіжних практик.

\section{ПЕРЕЛІК ВИКОРИСТАНИХ ДЖЕРЕЛ}

1. Закон України «Про аудиторську діяльність» №3126-XII від 22.04.1993 (в редакції 3 1.05.2016) [Електронний ресурс]. - Режим доступу: http://zakon3.rada.gov.ua/laws/show/3125-12.

2. Директива 2014/56/ЄС Європейського парламенту та Ради від 16 квітня 2014p. [Електронний ресурс]. Режим доступу: http://www.apu.com.ua/attachments/article/762/Direktiva\%202014-56-EU.pdf.

3. Бандура В., Кузів Д., Мелех В. Проблеми та перспективи розвитку аудиторської діяльності в Україні // В. Бандура, Д. Кузів, В. Мелех // Матеріали Міжнародної науково-практичної конференції «Розвиток соціальноекономічних систем в геоекономічному просторі: теорія, методологія, організація обліку та оподаткування» 11 12 травня 2017 р. (ТНТУ ім. І. Пулюя, м. Тернопіль) - 2017. - С.47-49.

4. Борисова Ю.Ю. Історико-правовий аналіз становлення аудиту / Ю.Ю. Борисова // Часопис Київського університету права. - 2015. - №3. - С. 387-390.

5. Бутинець Ф.Ф. Аудит: підручник для студентів спеціальності «Облік і аудит» вищих навчальних закладів. - 2-е вид., перероб. та доп. / Ф.Ф. Бутинець. - Житомир: ПП Рута, 2002. - 672 с.

6. Дерев’янко С.І. Аудит: навч. пос. / С.І. Дерев’янко, Н.П. Кузик, С.О. Олійник. - К.: «Центр учбової літератури», 2016. - 380 с.

7. Йосипович М. Виклики та перспективи розвитку аудиту в Україні // М. Йосипович // Фінансовий простір. - 2015. - №3(19). - С. 185-190.

8. Касич А.О. Розвиток ринку аудиторських послуг в Україні / А.О. Касич, І.М. Гноєва // Облік і фінанси АПК. - 2011. - № 1. - С. 76-80.

9. Касич А.О. Особливості розвитку аудиторських послуг в Україні та концептуальні підходи до їх класифікації / А.О. Касич, І.М. Гноєва // Вісник ЖДТУ / Економічні науки. - 2010. - № 4 (54). - С. $94-98$.

10. Медвідь С.В. Тенденції розвитку та проблеми вітчизняного ринку аудиторських послуг / С.В. Медвідь [Електронний ресурс]. - Режим доступу: http://www.sibs.uabs.edu.ua.

11. Міжнародні стандарти контролю якості, аудиту, огляду, іншого надання впевненості та супутніх послуг: Вид. 2015 р. Ч. 1,2: пер. $з$ англ. - Київ: Міжнар. Федерація бухгалтерів: Аудит. Палата України, 2016. - 1249 с.

12. Олійник С.В. Аудит в Україні: виклики та перспективи впровадження Директив ЄС / С.В. Олійник // Розвиток бухгалтерського обліку, фінансів та оподаткування в аграрному секторі економіки в умовах євроінтеграції: збірник матеріалів Х Міжнар. наук.-прак. конф. (24 листопада 2017 р.; м. Київ) / Відпов. за вил. Бездушна. - К.: ННЦ «IAE», 2017. - С. 202-206. 
13. Платонова I.А. Проблеми та перспективи аудиту в Україні / I.А. Платонова // Науковий вісник Полтавського університету економіки і торгівлі. - № 4 (49). - 2011 - С337-341.

14. Рудницький В.С. Аудит: навч. посіб. - 3-те вид., перероб і доп. / В.С. Рудиницький, Я.А. Гончарук. - К.: Знання, 2007. - 443 с.

15. Хоменко М.М. Сучасні тенденції розвитку аудиторської діяльності в Україні [Електронний ресурс] / М.М. Хоменко // Економічний вісник. Випуск 3 - 2016. - С. 113-119. - Режим доступу: http://ev.nmu.org.ua/docs/2016/3/EV20163_113-119.pdf.

\section{REFERENCES}

1.Zakon Ukrainy «Pro audytorsku diialnist» [Law of Ukraine “On Auditing”]. (n.d.). zakon3.rada.gov.ua/laws/show/3125-12. Retrieved from: http://zakon3.rada.gov.ua/laws/show/3125-12. [in Ukrainian].

2. Dyrektyva 2014/56/YES Yevropeiskoho parlamentu ta Rady vid 16 kvitnia 2014 r. [Directive 2014/56 / EU of the European Parliament and of the Council from April, 16 2014]. (n.d.). www.apu.com.ua/attachments/article/762/Direktiva\%202014-56-EU.pdf. Retrieved from: http://www.apu. com.ua/attachments/article/762/Direktiva\%202014-56-EU.pdf. [in Ukrainian].

3. Bandyra, V. \& Kuziv. D. \& Melekh, V. (2017). Problemu ta perspektyvy rozvytku audytorskoi diialnosti v Ukraini [Problems and prospects of audit activity development in Ukraine]. Proceedings from MIIM '17: Materialy Mizhnarodnoi naukovo-praktychnoi konferentsii «Rozvytok sotsialno-ekonomichnykh system v geoekonomichnomu prostori: teoriia, metodologiia, organizatsiia obliky ta opodatkuvannia» - Materials of the International Scientific and Practical Conference «Development of Socio-Economic Systems in the Geo-Economic Space: Theory, Methodology, Accounting Organization and Taxation». (pp. 47-49). Ternopil: TNTY im. I. Puliuia [in Ukrainian].

4. Borysova, Yu.Yu. (2015). Istoryko-pravovyi analiz stanovlennia audytu [Historical and legal analysis of audit formation]. Chasopys Kyivskogo universytetu prava - Journal of the Kyiv University of Law, 3, $387-390$ [in Ukrainian].

5. Bytunets, F.F. (2002). Aydit: pidruchnyk dlia stydentiv spetsialnosti «Oblik i audit» vyshchykh navchalnykh zakladiv [Audit: a textbook for students of the specialty "Accounting and Audit" of higher educational establishments], Zhytomyr: Ruta [in Ukrainian].

6. Derevianko S.I., Kuzyk N.P., Oliinyk S.O. (2016). Audyt [Audit], Kyiv: Tsentr uchbovoi literature. [in Ukrainian].

7. Iosypovych, M. (2015). Vyklyky ta perspertyvy rozvytku audytu v Ykraini [Challenges and prospects for the development of audit in Ukraine], Finansovyj prostir - Financial space, 3 (19), 185-190 [in Ukrainian].

8. Kasych, A.O. \& Gnoiava, I.M. (2011). Rozvytok rynku audytorskykh poslug v Ukraini [Development of the audit services market in Ukraine], Oblik i finansy APK - Accounting and finance of agroindustrial complex, 1, 76-80 [in Ukrainian].

9. Kasych, A.O. \& Gnoiava, I.M. (2010). Osoblyvosti rozvytku audytorskykh poslug v Ukraini ta kontseptualni pidkhody do yikh klasyfikatsii [Features of audit services development in Ukraine and conceptual approaches to their classification], Visnyk ZHDTU. Ekonomichni nauky - Bulletin of ZhSTU. Economic sciences, 4 (54), 94-98 [in Ukrainian].

10. Medvid', S.V. (n.d.). Tendentsii rozvytku ta problem vitchyznianogo rynku audytorskykh poslyg [Trends of development and problems of the audit services domestic market]. Retrieved from http://www.sibs.uabs.edu.ua. [in Ukrainian].

11. Mignarodni standarty kontroliu iakosti, ogliadu, inshogo nadannia vpevnenosti ta suputnikh poslug [International standards for quality control, audit, review, other assurance and related services] (2016). Kyiv: Mignarodna Federatsiia bukhalteriv: Audyt. Palata Ukrainy [in Ukrainian].

12. Oliinyk, Ye. (2017). Audyt v Ukraini: vyklyky ta perspertyvy vprovadgennia Dyrektyv YeS [Audit in Ukraine: challenges and prospects for the implementation of the EU Directives].Proceedings from: Materialy X Mizhnarodnoi naukovo-praktychnoi konferentsii «Rozvytok bukhalterskogo obliku, finansiv ta opodatkuvannia v agrarnomy sectori ekonomiky v umovakh yevrointegratsii» - Materials of the Xth International Scientific and Practical Conference «Development of Accounting, Finance and Taxation in the Agrarian Sector of the Economy in the Conditions of European Integration». (pp. 202-206). Kyiv: NNTS «IAE» [in Ukrainian].

13. Platonova, I.A. (2011). Problemy ta perspektyvy audytu v Ukraini [Problems and prospects of audit in Ukraine], Naukovyi visnyk Poltavskogo universytetu ekonomiky i tirgivli - Scientific bulletin of Poltava University of Economics and Trade, 4 (49), 337-341 [in Ukrainian].

14. Rudnytskyj. V.S. \& Goncharuk, Ya.A. (2007). Audut [Audit]. Kyiv: Znannia. [in Ukrainian].

15. Khomenko, M.M. (2016). Suchasni tendentsii rozvytku audytorskoi diialnosti v Ukraini [Modern trends in audit activity development in Ukraine], Ekonomichnyi visnyk - Economic bulletin, 3, 113-119. Retrieved from: http://ev.nmu.org.ua/docs/2016/3/EV20163_113-119.pdf. [in Ukrainian]. 